\title{
THE ANTI COAGULATION EFFECT OF Euphorbia hirta (SNAKE WEED) ON THE HUMAN BLOOD
}

\author{
AJAY JAMWAL ${ }^{1}$ \\ Department of Biotechnology, Shoolini Institute of Life Sciences and Business Management, Solan, H.P., India
}

ABSTRACT

This study aims at exploring, The Anti coagulation effect of Euphorbia hirta (snake weed) On the Human blood. The extract made for the study, consists of $6 \mathrm{ml}$ of distilled water Mixed with $4 \mathrm{~g}$ whole weed, crushed to get the extract. The technique used to detect the Clot is Photo-Optical method of detection. The study finds that the clotting does not prevail when apt extract is mixed in Blood.

KEYWORDS: Anti Coagulation, Euphorbia hirta, Photo-Optical Method

Anticoagulants in clinical laboratories can be defined as additives that prevent blood and/or plasma from clotting, ensuring that the constituent to be measured is non- significantly prior to the analytical processes. Anticoagulation occurs due to the binding of calcium ions as in EDTA, CITRATE or by inhibiting thrombin activity like HEPARI- NATES, HIRUDIN. (Essentials of Clinical Pathology, Shirish M kawthalkar, 2018)

Anticoagulant commonly used for hematological investigations is Ethylenediaminete- traacetic acid (EDTA), which is also known as Sequestrene, or Versene. It is the most commonly used anticoagulant for routine Hematological investigations.

The commonly used salts of EDTA are Disodium $\left(\mathrm{Na}_{2}\right)$ and Dipotassium $\left(\mathrm{K}_{2}\right)$. International committee for standardization in Hematological investigations recommends dipotassium EDTA since it is more soluble. Concentration 1.2 to $2.0 \mathrm{mg} \backslash \mathrm{ml}$ of blood based on anhydrous EDTA. (W.H.O, use of anticoagulants in diagnostic laboratory investigations, 2002).

\section{Euphorbia hirta}

It belongs to the plant family Euphorbiaceae; distributed throughout the hotter parts of India and Australia, usually found in waste places along the road sides. Also known as Snake Weed; it is a frequent used weed in Indian system of medicines for treatment of various diseases. Further its chemical extraction includes important chemicals like Gallic acid, 2, 4, 6-tri-o-galloyl-beta-d- glucose, choline, camphol, quercitrin etc. (Euphorbia hirta : its chemistry, traditional and medicinal uses, and pharmacological activities, Sunil Kumar, Rashmi Malhotra and Dinesh kumar., 2010).

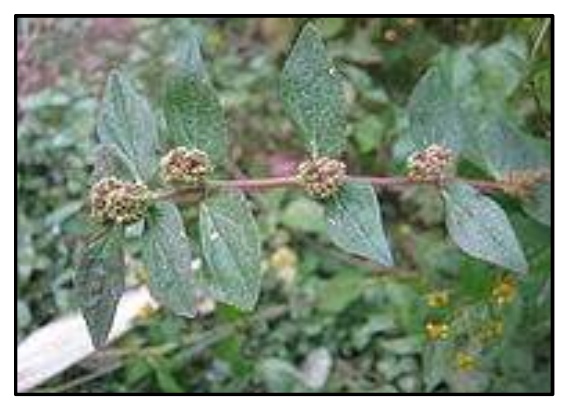

(Source, Wikipedia)

\section{MATERIALS AND METHODS}

Photo-optical technique of detection of coagulation of blood is used here. This technique involves the change in optical density or turbidity of the sample as the fibrin formation takes place. The results are usually recorded as the time taken to clot. (Table 1)

4 grams of fresh whole plant is taken and crushed with the help of $6 \mathrm{ml}$ of distilled water to obtain the plant extract. Three test tubes and one commercially available EDTA (k3) tube is taken. Label the test tubes as $\mathrm{t} 1, \mathrm{t} 2, \mathrm{p}$ and $\mathrm{k} 3$ where $\mathrm{t} 1$ and $\mathrm{t} 2$ stands for test, $\mathrm{p}$ stands for plain and $\mathrm{k} 3$ for EDTA. Add the samples of plant extract and whole blood to the test tubes as per the quantities prescribed in the following table:

Table 1: Samples Quantity for Photo Optical Technique

\begin{tabular}{|c|c|c|c|c|}
\hline Sample & t1 & t2 & P & EDTA \\
\hline Plant Extract & $0.5 \mathrm{ml}$ & $1 \mathrm{ml}$ & - & - \\
\hline Whole Blood & $1.5 \mathrm{ml}$ & $2 \mathrm{ml}$ & $1 \mathrm{ml}$ & $1.5 \mathrm{ml}$ \\
\hline
\end{tabular}

${ }^{1}$ Corresponding author 


\section{RESULTS}

Four test tubes are taken and labeled as $\mathrm{t} 1, \mathrm{t} 2, \mathrm{P}$ and EDTA (commercially available, k3), After fifteen minutes, the $\mathrm{P}$ test tube is partially clotted, while there is no clot formation in rest of the test tubes, Ater 25 minutes, blood in $\mathrm{t} 1$ test tube is partially clotted, in P test tube it is completely clotted, while in others there is no clot in the blood, After 35 minutes, blood in $\mathrm{t} 1$ and $\mathrm{P}$ test tubes is clotted while there is no clot formation in blood in $\mathrm{t} 2$ and EDTA test tubes. This is same even after 12 hours indicating that there is no clot formation when appropriate concentration of Euphorbia hirta plant extract is added to the human blood. Also, After 12 hours when the blood samples in these test tubes ( 2 and EDTA) are observed under microscope (100x oil), it shows the crenation and spherocytic structure of erythrocytes which is a point of similarity between the Euphorbia hirta plant extract and EDTA, when prolonged stored. (Essentials of clinical pathology, Shirish M kawthalkar., 2018). (Figure 1, 2)

\section{Ethical Cosideration}

The blood used in this study protocol is colleted from the same person (author) with my own choice, I have allowed the phlebotomist (from my college) to take the blood with my own concern.

Following are the observations for Photo Optical Technique: (Table 2,3)

Table 2: Photo Optical Technique Observation

\begin{tabular}{|c|c|c|c|c|}
\hline $\begin{array}{c}\text { TIME TAKEN BY BLOOD TO } \\
\text { CLOT }\end{array}$ & $\mathbf{t 1}$ & $\mathbf{t 2}$ & $\mathbf{P}$ & EDTA \\
\hline Ater 15 minutes & No clot (NC) & No clot (NC) & Partially clotted & No clot (NC) \\
\hline After 25 minutes & Partially clotted & NC & Clotted (C) & NC \\
\hline After 35 minutes & Clotted (C) & NC & C & NC \\
\hline After 1 hour & $\mathrm{C}$ & NC & $\mathrm{C}$ & NC \\
\hline After 2 hours & $\mathrm{C}$ & $\mathrm{NC}$ & $\mathrm{C}$ & $\mathrm{NC}$ \\
\hline After 5 hours & $\mathrm{C}$ & $\mathrm{NC}$ & $\mathrm{C}$ & $\mathrm{NC}$ \\
\hline After 12 hours & $\mathrm{C}$ & $\mathrm{NC}$ & $\mathrm{C}$ & $\mathrm{NC}$ \\
\hline
\end{tabular}

Table 3: Similarities in $\mathbf{t} 2$ and EDTA test tube (prolonged storage)

\begin{tabular}{|c|c|c|}
\hline SIMILARITIES & EDTA BLOOD SLIDE & PLANT EXTRACT BLOOD SLIDE \\
\hline $\begin{array}{c}\text { Crenation and spherocytic c change in } \\
\text { RBCs }\end{array}$ & Present & Present \\
\hline
\end{tabular}

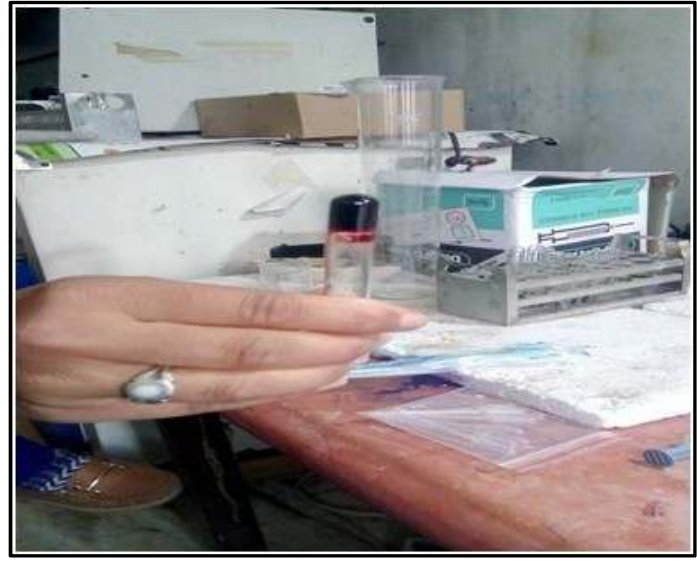

Figure 1: Clotted Blood

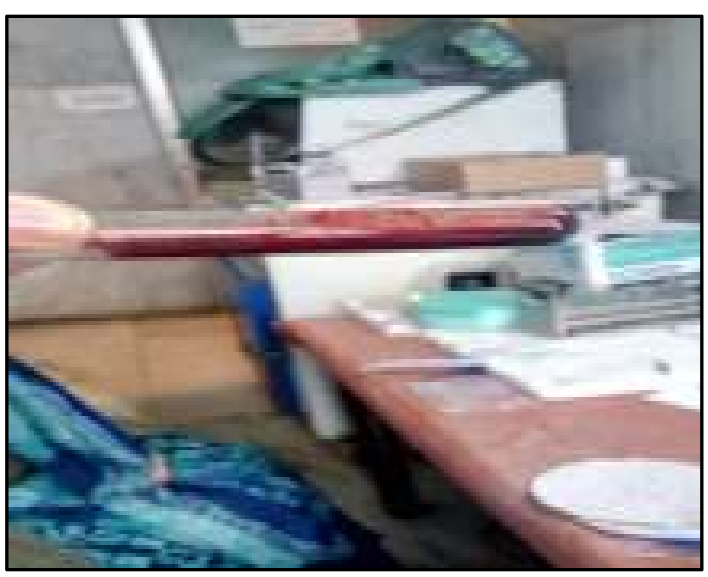

Figure 2: Blood containing Snake weed extract (No Clot Formed) 


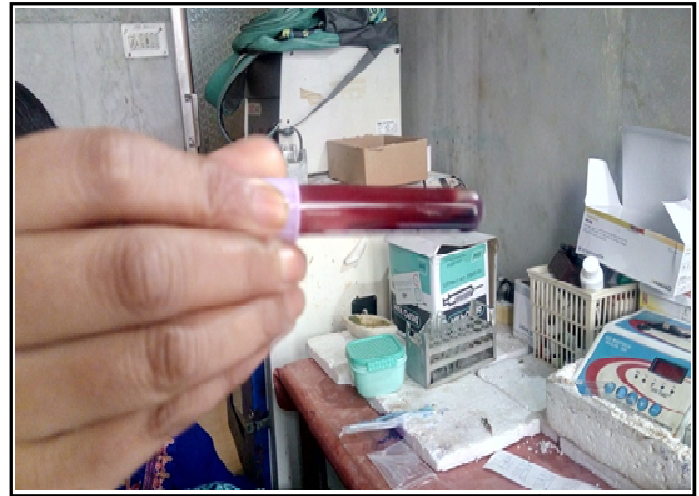

Figure 3: Anticoagulant Blood in EDTA Tube

\section{DISCUSSION}

\section{Euphorbia hirta v/s EDTA}

In clinical laboratories, the most commonly used anti-coagulant is ETHYLENE DIAMINE TETRA-ACETIC ACID (EDTA). It is economically expensive when compared with the number of clinical investigations done every day in hospitals and clinical laboratories. If this weed extract is somehow substituted with EDTA. This can be proved as a boon in the Medical Laboratory science especially in developing countries like India. It needs further research and attention so that it can be a cheapest source of anticoagulant in India.

\section{ACKNOWLADGEMENT}

I would like to acknowledge Dr. Meenu Thakur, H.O.D of Biotechnology, SILB, Solan, Dr. Manisha ,Asst. Professor, S.I.L.B ,Solan \& Miss Pooja Singh, Histotechnician, Govt. Medical College, Jammu, who provided me patient advice and guidance throughout the research process. Thank you all for your unwavering support.

\section{REFERENCES}

Shirish M. Kawthalkar, 2018. Essentials of clinical pathology $\left(2^{\text {nd }}\right.$ ed.), Jaypee Brothers Medical publishers (p) ltd, New Delhi, 196-198.

W.H.O Document, 2002. "Use of anticoagulants in diagnostic laboratory investigations". Geneva, 5-7.

Kumar S., Malhotra R. and Kumar D., 2010. Euphorbia hirta: its chemistry, traditional and medicinal uses and pharmacological activities, pharmacognosy review, Medknow Publications and media pvt. Ltd., Mumbai.
Mohammad Abu Bin Nyeem, Mohammad Sadul Haque, Mohammad Akramuzzaman, Rabeya Siddika, Sanjeeda Sultana, BM Rabiul Islam., 2017. Euphorbia hirta Linn. A wonderful miracle plant of mediterranean region: A review, Journal of Medicinal Plants Studies, Delhi.

Al-Snaf A.E., 2017. Pharmacology and therapeutic potential of Euphorbia hirta (Syn: Euphorbia pilulifera) A review, IOSR Journal of Pharmacy.

Akomas S.C., Ijioma S.N. and Emelike C.U., 2015 .Effect of Euphorbia hirta on haematological and biochemical indices in albino rats. Applied Journal of Hygiene : 1-5.

Rastogi R.P. and Mehrotra B.N., 2002. Central Drug Research Institute; Compendium of Indian Medicinal Plants ( $3^{\text {rd }}$ volume), Lucknow.

Aquil M. and Khan I.Z., 1999. Euphorbianin a new glycoside from Euphorbia hirta Linn. Global J. Pure Applied Sci.

Saravanan R., Dhachinamoorthi D., Senthilkumar K., Srilakshmi M. and Sri T.D., 2012. Antibacterial activity of Euphorbia hirta extracts. I.J.R.A.P : 439-441.

Gayathri A. and Ramesh K.V., 2013. Antifungal activity of Euphorbia hirta L. inflorescence extract against Aspergillus flavus- A mode of action study. Int. J. Curr. Microbiol App. Sci., 31-37.

Upadhyay A., Chattopadhyay P., Goyary D., Mazumder P.M. and Veer V., 2014. Anti-inflammatory effect of Euphorbia hirta leaf extract in rats and modulation of inflammation-associated prostaglandins (PGE-2) and nitric oxide (NO) expression in RAW264.7 macrophage. Journal of Pharmaceutical Sciences and Pharmacology : 6873.

Galvez J., Zarzuelo A., Crespo M.E., Lorente M.D., Ocete M.A. and Jiménez J., 1993. Antidiarrhoeic activity of Euphorbia hirta extract and isolation of an active flavonoid constituent. Planta Med., 59(4): 333- 336.

Adedapo A.A., Abatan M.O., Idowu S.O. and Olorunsogo O.O., 2005. Effects of chromatographic fractions of Euphorbia hirta on the rat serum biochemistry. African Journal of Biomedical Research, 8: 185189. 